\title{
Peran Struktur Dewan Dalam Mempengaruhi Kinerja Pada Nilai Perusahaan Keluarga
}

\author{
Santi Yopie \\ Universitas Internasional Batam \\ Santi.yopie@uib.ac.id \\ Supriyanto \\ Universitas Internasional Batam \\ Supriyanto.lim@uib.ac.id \\ Budi Chandra \\ Universitas Internasional Batam \\ Budi.Chandra@uib.ac.id
}

\begin{abstract}
Abstrak
The family company is synonymous with the characteristics to inherit its company from one generation to the next. The average family company can only survive and inherit up to third generation (Wahjono, Wajoedi, \& Idrus, S, 2014). However, there are also have some family companies especially in the field of estate in Scotland that can last up to 400, 600 even 800 years (Belmonte, Seaman, \& Bent, 2016). The culture and application of the board structure of each family company varies greatly. The purpose of this study was to determine the effect of board structure (CEO family / non-family, professional qualification, board size, and independent commissioner) on the value of the company in the family enterprise. This research method is analyzed by multiple linear regression on panel data that is 125 family company in BEI 2010-2014. The results of this study indicate that family firms run by non-family (professional) CEOs will be higher in corporate value than the family $C E O$. Professional qualifications have a significant negative influence on the value of the company. The size of the board has a significant positive influence on firm value. Independent commissioners have no significant influence on the value of family firms.

Kata Kunci Board Structure, CEO Family, CEO Professional, Firm Value, Professional Qualification, Family firm
\end{abstract}

\section{I.PENDAHULUAN}

Perusahaan keluarga identik dengan karakteristik untuk mewarisi perusahaannya dari satu generasi ke generasi berikutnya. Rata-rata perusahaan keluarga hanya mampu bertahan dan mewarisi sampai ke generasi ketiga (Wahjono, Wajoedi, \& Idrus, S, 2014). Namun, ada juga perusahaan keluarga khususnya dibidang estate di Scotland yang mampu bertahan sampai 400, 600 bahkan 800 tahun (Belmonte, Seaman, \& Bent, 2016). Budaya dan penerapan struktur dewan masing-masing perusahaan keluarga sangat bervariasi. Maka, kunci strategi penerapan struktur dewan pada perusahaan keluarga untuk mampu bertahan dari satu ke generasi berikutnya merupakan hal yang sangat menarik dan unik untuk diteliti.

Beberapa penelitian menyatakan bahwa kinerja perusahaan keluarga lebih baik dari perusahaan non-keluarga dilihat dari sisi tata kelola perusahaannya (Anderson \& Reeb, 2003; Park \& Shin, 2016; Villalonga \& Amit, 2006). Di Indonesia juga terdapat banyak penelitian mengenai kinerja perusahaan keluarga dengan menggunakan proxi tata kelola perusahaan (Darmadi, 2013; Lieyanto \& Indriyani, 2014; Limbago \& Juniarti, 2014). Tata kelola perusahaan pada umumnya akan meningkatkan kinerja perusahaan keluarga tetapi peran komisaris tidak mempengaruhi kinerja perusahaan keluarga di Indonesia (Darmadi, 2013; Robin \& Amran, 2016). Dari pernyataan diatas telah dibuktikan bahwa hasil penelitian di Indonesia mengenai tata kelola perusahaan terhadap kinerja perusahaan keluarga mempunyai hasil yang bervariasi. Hal ini memotivasi untuk meneliti mengenai sebenarnya apa yang merupakan kunci utama pada tata kelola perusahaan keluarga dalam upaya meningkatkan kinerja perusahaan. 
Dewan direksi berperan sangat penting jika dilihat dari sisi tata kelola perusahaan. Hal ini karena dewan direksi yang menjalani pelaksanaan operasional perusahaan. Salah satu contoh yaitu direktur keuangan mempunyai peran yang strategis sebagai roda penggerak sebuah perusahaan. Seorang direktur keuangan dituntut untuk dapat mengelola keuangan secara tepat dan mampu menyusun strategi untuk mendongkrak peningkatan pendapatan perusahaan. Hal ini dapat diwujudkan jika direktur keuangan yang menjabati pada perusahaan publik lebih baik memiliki sertifikasi CA (Chartered Accountant).

Direksi keuangan yang mempunyai sertifikasi profesional akuntan sangat penting dalam meningkatkan dan memperkuat kualitas pelaporan keuangan dan tata kelola perusahaan sehingga pada akhirnya akan mempunyai efek positif dalam meningkatkan nilai perusahaan dan mendorong adanya peningkatan dan pertumbuhan ekonomi dan investasi di Indonesia. Masing-masing direksi jika telah memiliki kualifikasi profesi yang profesional pada bidang masing-masing maka diharapkan akan mengambil keputusan yang tepat dan berkualitas dalam peningkatan kinerja perusahaan. Penelitian ini akan ditambahkan dengan variabel baru yaitu kualifikasi professional. Oleh karena itu, pada pembahasan penelitian yang dilakukan ini, akan menggunakan variabel kualifikasi profesional direksi sebagai hipotesis dalam penelitian ini.

Ada beberapa perusahaan keluarga yang sukses dan mempunyai nilai perusahaan yang baik serta sangat terkenal yaitu Lim Sui Liong pemilik Salim Grup, Kris Wiluan pemilik PT. Citra Tubindo Tbk, Ciputra pemilik Ciputra Grup dan Abidin pemilik PT. Sat Nusapersada, Tbk (Robin \& Amran, 2016). Perusahaan-perusahaan yang tersebut diatas masih dimiliki dan dikendali oleh pemiliknya. Perusahaan publik di Indonesia dituntut untuk mengungkapkan praktek tata kelola perusahaan pada laporan tahunannya (Peraturan Otoritas Jasa Keuangan, 2016). Alasan OJK untuk menerapkan peraturan yang disebutkan diatas karena tata kelola perusahaan berperan penting dalam meningkatkan kinerja serta nilai perusahaan secara terstruktur.

Pada perusahaan keluarga, biasanya lebih memilih dewan direksi dijabati oleh anggota keluarga. Hal ini karena hubungan antara pemilik perusahaan dan pengelola perusahaan akan mempunyai tujuan yang sama sehingga dapat meminimalkan permasalahan yang sering dialami yaitu mengenai masalah hubungan keagenan. Oleh karena itu, pada peraturan OJK, Dewan direksi akan di awasi oleh dewan komisaris. Dewan direksi dan pemegang jabatan komisaris merupakan pihak yang sangat berperan penting dalam perihal menentukan arah perusahaan. Oleh karena itu, karakteristik dewan direksi dan komisaris perlu di tinjau lebih detail supaya dapat menciptakan tata kelola perusahaan yang handal. Hal ini menjadi isu yang mendorong untuk melakukan penelitian dengan menggunakan struktur dewan direksi dan komisaris pada perusahaan keluarga. Apakah mekanisme tata kelola perusahaan seperti CEO Keluarga, kualifikasi profesional direksi, ukuran dewan direksi, dan komisaris independen dapat mempengaruhi kinerja perusahaan keluarga?

\section{LANDASAN TEORI}

CEO Keluarga. Perusahaan keluarga ada beberapa yang dikelola oleh pihak yang berasal dari salah satu anggota keluarga dan ada juga perusahaan keluarga yang dikelola oleh dari bukan pihak keluarga contohnya CEO non-keluarga yang professional dimana tidak ada hubungan darah saudara dengan pemilik perusahaan. Efek manajemen yang dikelola oleh anggota yang berasal dari CEO keluarga dan CEO non-keluarga akan menghasilkan kinerja yang pada akhirnya akan menghasilkan nilai perusahaan yang berbeda (Anderson \& Reeb, 2003; Villalonga \& Amit, 2006). Perusahaan keluarga yang CEOnya dijabati oleh anggota keluarga akan cenderung mempunyai pengetahuan yang lebih banyak terhadap perusahaannya dan dapat membangun jaringan sosial yang baik (Chung, Lubatkin, Roger \& Owers, 1987). Ada beberapa penelitian yang berargumen bahwa perusahaan yang dikelola oleh manajer non-keluarga yang professional akan mengelola perusahaannya lebih baik dari pada manajer keluarga.

Kualifikasi Profesional. Kualifikasi profesional direksi adalah direksi yang mempunyai sertifikasi profesi atas keahlian bidang tertentu. Perusahaan seharusnya mencari kandidat direksi yang berkualitas tinggi dalam mengendalikan manajemen (Fairchild \& Li, 2005). Akan tetapi, kadang-kadang terdapat kesulitan untuk menarik para profesional untuk menjabati di perusahaan keluarga. Pada umumnya, perusahaan keluarga lebih mementingkan anggota keluarganya untuk menjabati sebagai anggota dewan direksi, sehingga tidak adanya kebutuhan atas direksi yang profesional. Akan tetapi, dengan adanya regulasi tertentu mengharuskan perusahaan keluarga untuk menggunakan direksi yang berkualifikasi profesional. Salah satu contoh yaitu untuk menjabati direktur pada Bank Perkreditan Rakyat, mengharuskan kandidatnya telah memiliki sertifikasi profesi yang telah diakui sesuai Peraturan 
OJK Nomor 44/POJK.03/2015. Contoh lainnya adalah direktur keuangan yang menandatangani laporan keuangan perusahaan go public harus memiliki sertifikasi Chartered Accountant.

Ukuran dewan direksi. Struktur dewan dapat membatasi tingkat praktek terhadap timbulnya manajemen manipulasi laba dengan memanfaatkan fungsi pengendalian pada operasional manajemen. Hal ini mendorong adanya dorongan untuk meningkatkan kualitas dalam pelaporan laba dan kinerja perusahaan terutama yang tercermin pada nilai perusahaan yang dimana dapat dilihat dari peningkatan atas nilai harga saham dan nilai perusahaan (Rashid, 2011). Berdasarkan argumen Rashid (2011), dapat disimpulkan bahwa perusahaan yang mempunyai semakin banyak anggota dewan yang menjabati pada jabatannya maka akan semakin tinggi pengaruhnya terhadap peningkatan nilai perusahaan.

Komisaris independen. Aktivitas pemantauan terhadap manajer akan menjadi semakin efektif apabila jumlah dewan independen lebih dominan. Peran komisaris independen dapat menjamin dan melakukan sesuai dengan tugasnya dalam menghindari kemungkinan terjadinya praktik moral hazard. Kemungkinan terjadinya praktik moral hazard dapat berupa tindakan yang dilakukan oleh para manajemen atau direktur perusahaan demi mencapai kepentingannya diri mereka sendiri melalui pemilikan perkiraan-perkiraan akrual yang berdampak pada manajemen manipulasi laba sehingga dapat memaksimalkan nilai perusahaan. Hal ini telah membuktikan dan menyatakan jika terdapat semakin banyak anggota komisaris independen pada suatu perusahaan, maka akan mengurangi praktik manajemen manipulasi laba pada suatu perusahaan. Hal ini dapat secara otomatis mendorong dengan adanya peningkatan pada nilai perusahaan. Oleh karena itu, proporsi anggota dewan komisaris independen pada suatu perusahaan akan mempunyai dan berpengaruh secara positif terhadap nilai perusahaan (Fama \& Jensen, 1983).

Ada beberapa penelitian yang berargumen bahwa perusahaan yang dikelola oleh manajer nonkeluarga yang professional akan mengelola perusahaannya lebih baik dari pada manajer keluarga (Hambrick \& Mason, 1984; Kosnik, 1987; Daily \& Dollinger, 1992; Anderson, Dure, \& Reeb, 2009). Hal ini dikarenakan bahwa manajer non-keluarga yang professional lebih produktif dibandingkan dari pada manajer keluarga. Oleh karena itu, maka pada penelitian ini akan menarik satu hipotesis yang menyatakan bahwa: $\mathrm{H}_{1}=$ CEO keluarga yang menjabati peran CEO pada perusahaan keluarga akan mempunyai pengaruh yang signifikan negatif terhadap nilai perusahaan pada perusahaan keluarga.

Direktur yang memiliki berbagai kualifikasi profesional dalam bidang hukum, keuangan, akuntansi, dan konsultasi dapat memberikan nilai tambah dalam pembahasan perumusan strategi perusahaan (Anderson \& Reeb, 2003). Oleh karena itu, semakin banyak direksi yang memiliki kualifikasi profesional, maka semakin tinggi kinerja perusahaan keluarga, maka berhipotesis bahwa: $\mathrm{H}_{2}=$

Kualifikasi profesional direksi berpengaruh signifikan positif terhadap nilai perusahaan pada perusahaan keluarga.

Perusahaan keluarga yang mempunyai semakin banyak jumlah anggota dewan direksi yang menjabati di perusahaannya, maka akan cenderung semakin efektif mereka dalam memberikan nasihat dan pandangan yang positif pada opsi strategi perusahaan karena telah memiliki kemampuan dan sumber daya yang banyak dalam memecahkan dan memberikan solusi pada penyelesaian permasalahan (Pearce \& Zahra, 1991). Oleh karena itu, perusahaan keluarga yang mempunyai semakin banyak anggota dewan direksi akan semakin tinggi jika dilihat dari nilai perusahaan (Rashid, 2011; Vitor, 2012; Fallatah \& Dickins, 2012). Oleh karena itu, maka pada penelitian ini menarik satu hipotesis bahwa: $\mathrm{H}_{3}=$ Jumlah anggota yang tercermin pada ukuran dewan direksi yang menjabat di perusahaan keluarga akan berpengaruh secara signifikan dan berefek positif terhadap nilai perusahaan pada perusahaan keluarga.

Aktivitas pemantauan terhadap manajer akan menjadi lebih efektif jika jumlah dewan independen lebih dominan. Komisaris independen akan menjalankan tugasnya secara baik dalam menjamin serta menghindari kemungkinan akan terjadinya praktik moral hazard yang dapat dilakukan oleh para manajemen / direktur perusahaan untuk kepentingannya melalui pemilikan perkiraan-perkiraan akrual yang berdampak pada manajemen manipulasi laba sehingga dapat memaksimalkan nilai perusahaan. Hal ini membuktikan serta menunjukkan jika perusahaan keluarga yang mempunyai semakin banyak komisaris independen pada suatu perusahaan, maka akan terjadi semakin kuat pengelolaan terhadap perusahaan pada akhirnya akan membawa efek positif yaitu meningkatkan nilai perusahaan. Oleh karena itu, perusahaan keluarga yang mempunyai proporsi anggota dewan komisaris independen yang banyak akan memberikan pengaruh yang signifikan secara positif terhadap nilai perusahaan (Fama \& Jensen, 1983; John \& Senbet, 1998; Fallatah \& Dickins, 2012). Oleh karena itu, penelitian ini menarik satu hipotesis bahwa bahwa: $\mathrm{H}_{4}=$ Proporsi anggota komisaris independen yang banyak pada perusahaan 
keluarga akan memberikan pengaruh signifikan positif terhadap nilai perusahaan pada perusahaan keluarga.

Berdasarkan pembahasan penelitian yang dilakukan, maka dapat diilustrasikan serta disimpulkan pada gambar model penelitian yang digunakan dalam penelitian ini adalah sebagai berikut:

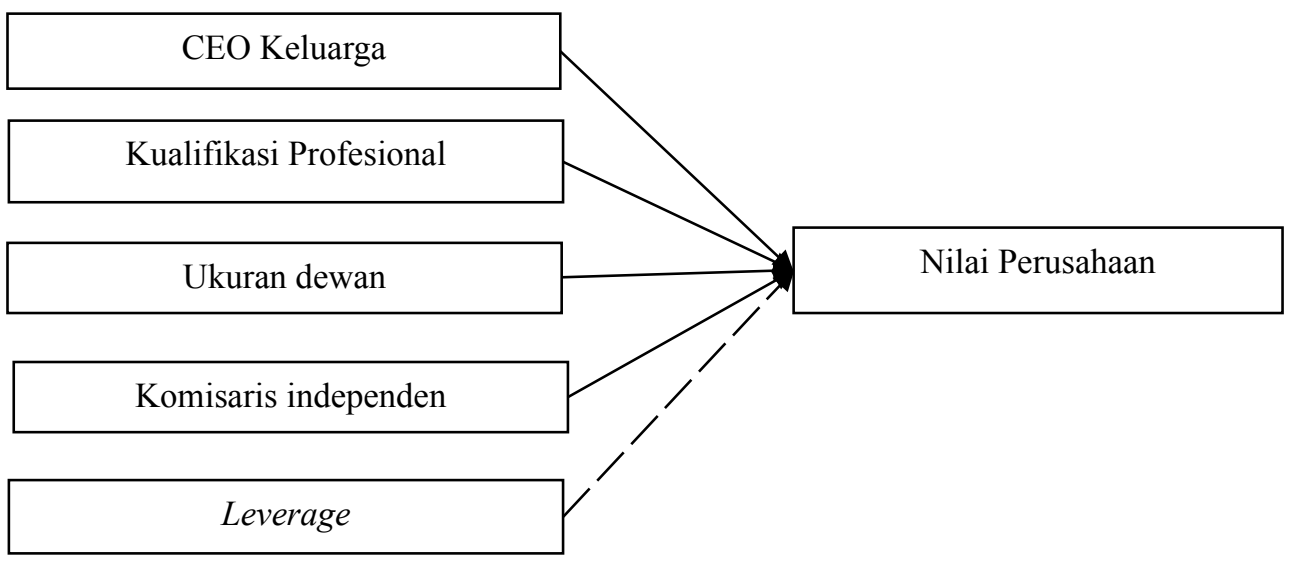

Sumber: Gill dan Obradovich (2012), Robin dan Amran (2016)

\section{METODOLOGI PENELITIAN}

Penelitian yang dilakukan adalah bersifat kuantitatif, dan dilakukan teknik analisa secara regresi linear berganda. Data yang diteliti pada penelitian ini merupakan penggabungan dari dua metode yaitu secara cross sectional (antar perusahaan) dan time series (antar periode) yang disebut data panel. Populasi yang digunakan dari penelitian yang dilakukan ini berupa perusahaan-perusahaan keluarga yang telah terdaftar di Bursa Efek Indonesia (BEI) selain bank, perusahaan asuransi dan perusahaan keuangan. Perusahaan keuangan dikecualikan dari sampel karena kegiatan operasional perusahaan keuangan diatur dalam aturan-aturan khusus yang berbeda dari perusahaan non-keuangan.

Pengambilan sampel dilakukan dengan menggunakan metode purposive sampling. Sampel yang dipilih dan digunakan dari penelitian yang dilakukan ini adalah perusahaan-perusahaan yang dikategorikan sebagai perusahaan keluarga. Sampel yang terpilih harus memenuhi beberapa kriteria sebagai berikut:

a. Perusahaan tersebut telah terdaftar IPO selama 5 (lima) tahun yang telah terdaftar secara berturutturut yang terhitung mulai dengan tahun 2010 sampai tahun 2014.

b. Perusahaan telah memiliki data laporan keuangan selama 5 (lima) tahun yang telah terdaftar secara berturut-turut yang terhitung mulai tahun 2010 sampai tahun 2014.

c. Memiliki kepemilikan keluarga (kepemilikan saham langsung dan tidak langsung) minimal 20\% dalam perusahaan. Definisi kepemilikan keluarga adalah harus memenuhi criteria berikut: (1) pihak keluarga memiliki minimum $20 \%$ saham dari perusahaan, (2) individu atau perusahaan pribadi (listed \& non-listed) mempunyai kepemilikan saham minimum 20\% dari perusahaan. Jika perusahaan pribadi yang listed, maka akan menelusuri perusahaan induknya atau kepemilikan terbesarnya.

Data yang digunakan pada penelitian yang dilakukan ini adalah data yang berupa sekunder (secondary data) yang dipublikasikan. Data-data yang digunakan pada penelitian tersebut berupa laporan tahunan (annual report) perusahaan dan data nilai pasar yang terdaftar pada salah satu bursa di Indonesia yaitu BEI dengan periode 2010-2014. Operasional variabel yang digunakan dalam penelitian ini terdiri dari empat variabel independen yaitu CEO keluarga/profesional, kualifikasi profesional direksi, ukuran dewan direksi, komisaris independen dan satu variabel dependen yaitu nilai perusahaan.

Berikut dibawah ini adalah pengukuran variabel dependen dan independen yang akan digunakan dalam penelitian ini: 


\begin{tabular}{|l|l|}
\hline \multicolumn{1}{|c|}{ Variabel } & \multicolumn{1}{c|}{ Measurement } \\
\hline Nilai Perusahaan & Tobin's Q \\
\hline CEO Keluarga Profesional & $\begin{array}{l}\text { dummy, jika CEO keluarga diberikan kode 1, jika CEO Profesional } \\
\text { diberikan kode 0 }\end{array}$ \\
\hline Kualifikasi Profesional Direksi & $\begin{array}{l}\text { \% direksi yang mempunyai gelar profesi seperti CA, } \\
\text { CPA,CMA,CISA,CFA, atau setar dibagian dengan total anggota dewan } \\
\text { direksi }\end{array}$ \\
\hline Ukuran Dewan Direksi & Jumlah anggota dewan direksi (Gill \& Obradovisch, 2012) \\
\hline Komisaris Independen & \% komisaris independen dibagikan ke total anggota komisaris \\
\hline
\end{tabular}

Sumber: Gill dan Obradovisch, 2012; Robin dan Amran, 2016

Berdasarkan model penelitian yang akan dilakukan pada penelitian ini, maka dapat ditulis model regresi yang akan diuji dalam penelitian ini adalah sebagai berikut:

Nilai Perusahaan $=a+b_{1}$ CEOKeluarga $_{i t}+b_{2}$ Kualifikasiprofesional $_{i t}+b_{3}$ ukurandewan $_{\text {it }}+b_{4}$ komisarisindependen $_{\text {it }}+$ leverage $_{i t}+\mathrm{e}_{\mathrm{it}}$

Keterangan:

a : Konstanta

b : Koefisien regresi variabel independen

i : : Entitas ke-i

$t \quad:$ Periode ke-t

e $\quad:$ Error

\section{HASIL PENELITIAN}

Data yang digunakan pada penelitian yang dilakukan ini adalah merupakan analisis data dari data sekunder (secondary data). Objek penelitian yang dilakukan pada penelitian ini adalah berupa laporan keuangan (financial report), tahunan perusahaan (annual report) yang terdaftar di Bursa Efek Indonesia pada periode 2010 sampai dengan 2014. Sampel yang digunakan adalah perusahaan yang merupakan perusahaan keluarga yang terdaftar di bursa Indonesia yaitu BEI yang sesuai dengan kriteriakriteria sampel yang telah diterterakan pada metode penelitian diatas adalah sejumlah 125 perusahaan. Berdasarkan tabel 1 menunjukkan bahwa perusahaan keluarga cenderung memilih untuk dijabati oleh CEO keluarga daripada CEO non keluarga (profesional).

Berdasarkan tabel 2 menunjukkan bahwa perusahaan keluarga masih sangat minim jumlah direksi yang mempunyai kualifikasi profesional, hal ini dibuktikan bahwa rata-rata perusahaan keluarga hanya memiliki $6,5 \%$ direksi yang mempunyai kualifikasi profesional. Jumlah dewan direksi pada perusahaan keluarga rata-rata adalah 4 anggota, dan komposisi komisaris independen adalah $40 \%$. Hal ini menyatakan bahwa pada dasarnya perusahaan yang dimiliki oleh keluarga yang terdaftar di BEI rata-rata telah mematuhi peraturan BAPEPAM yang menyatakan minimal anggota dewan direksi adalah 3 (tiga) orang (UU NO. 40 Tahun 2007) dan komisaris independen dengan komposisi minimal 30\% (Pedoman tentang Komisaris Independen, 2004). Rata-rata ukuran dewan direksi di negara Indonesia adalah 4 (empat) anggota (Yopie \& Itan, 2016). Nilai perusahaan perusahaan keluarga rata-rata berkisar pada $136 \%$ yang artinya rata-rata perusahaan keluarga mempunyai nilai saham yang lebih tinggi daripada nilai buku perusahaan tersebut. Struktur modal perusahaan keluarga di BEI rata-rata cenderung menggunakan hutang $52,74 \%$ dan sisanya dibiayain oleh modal $47,26 \%$.

Dilihat dari hasil uji deskriptif, maka dapat diketahui bahwa perusahaan keluarga yang terdapat di Bursa Efek Indonesia (BEI) masih cenderung memilih CEO yang berasal dari keluarga dengan tidak mempertimbangkan tingkat profesionalismenya. Anggota dewan direksi yang banyak dalam menjabati di perusahaan keluarga tidak akan mempunyai efek yang signifikan jika tidak didukung dengan kualifikasi professional yang dimiliki oleh masing-masing direksi. Hal ini menjadi salah satu penemuan bahwa adanya kepentingan untuk meningkatkan kualitas direksi yang menjabat di perusahaan keluarga dalam upaya untuk meningkatkan nilai perusahaan. 
Tabel 1

Hasil Uji Statistik Frekuensi CEO

\begin{tabular}{|l|r|r|}
\hline \multicolumn{1}{|c|}{ Variabel } & Frekuensi & \multicolumn{2}{c|}{ Persentase } \\
\hline CEO Keluarga & 68 & $54 \%$ \\
\hline CEO Profesional & 57 & $46 \%$ \\
\hline Total & 125 & $100 \%$ \\
\hline
\end{tabular}

Tabel 2

Hasil Uji Statistik Deskriptif

\begin{tabular}{|l|r|r|r|r|}
\hline \multicolumn{1}{|c|}{ Variabel } & \multicolumn{1}{c|}{ Min } & \multicolumn{1}{c|}{ Max } & \multicolumn{1}{c|}{ Mean } & \multicolumn{1}{c|}{ Std Dev } \\
\hline Kualifikasi Profesional & 0,0000 & 1,0000 & 0,0658 & 0,1403 \\
\hline Ukuran Dewan & 2,0000 & 12,0000 & 4,2824 & 1,8021 \\
\hline Komisaris Independen & 0,2000 & 0,7500 & 0,4060 & 0,1117 \\
\hline Leverage & 0,0519 & 1,4408 & 0,5274 & 0,2287 \\
\hline Nilai Perusahaan & 0,3577 & 9,7673 & 1,3640 & 1,1311 \\
\hline
\end{tabular}

Tabel 3

Hasil Uji Statistik Regresi Linear Berganda

\begin{tabular}{lr}
\hline \multicolumn{2}{c}{ Regression Statistics } \\
\hline Multiple R & 0,3595 \\
R Square & 0,1292 \\
Adjusted R Square & 0,1222 \\
Standard Error & 1,6757 \\
Observations & 625 \\
\hline
\end{tabular}

ANOVA

\begin{tabular}{|c|c|c|c|c|c|}
\hline & $d f$ & $S S$ & $M S$ & $F$ & $\begin{array}{c}\text { Significance } \\
F \\
\end{array}$ \\
\hline Regression & 5,0000 & 257,9606 & 51,5921 & 18,3728 & 0,0000 \\
\hline Residual & 619,0000 & 1738,2000 & 2,8081 & & \\
\hline \multirow[t]{2}{*}{ Total } & 624,0000 & 1996,1606 & & & \\
\hline & Coefficients & $\begin{array}{c}\text { Standard } \\
\text { Error }\end{array}$ & $t$ Stat & P-value & \\
\hline Intercept & 0,6489 & 0,3280 & 1,9783 & 0,0483 & \\
\hline CEO Keluarga & $-0,5367$ & 0,1370 & $-3,9183$ & 0,0001 & \\
\hline Kualifikasi Profesional & $-1,3601$ & 0,4561 & $-2,9817$ & 0,0030 & \\
\hline Ukuran Dewan Direksi & 0,1670 & 0,0362 & 4,6133 & 0,0000 & \\
\hline Komisaris Independen & 0,6145 & 0,6513 & 0,9435 & 0,3458 & \\
\hline Leverage & 0,7143 & 0,1180 & 6,0519 & 0,0000 & \\
\hline
\end{tabular}


Berdasarkan hasil uji pada tabel 3 diatas, menunjukkan bahwa model penelitian yang digunakan yaitu struktur dewan secara simultan dapat mempunyai pengaruh yang signifikan dan berefek secara positif terhadap nilai perusahaan pada perusahaan keluarga. Hal ini dapat dilihat dari hasil uji $\mathrm{F}$ dengan signifikansi 0,0000 . Variabel yang digunakan untuk menjelaskan struktur dewan yaitu CEO keluarga, Kualifikasi profesional, ukuran dewan, dan komisaris independen dapat menjelaskan pengaruh terhadap nilai perusahaan sebesar $12,22 \%$, sisanya $87.78 \%$ dipengaruhi oleh variable-variabel lain yang tidak terdapat pada penelitian ini dan tidak digunakan pada penelitian ini. Dilihat dari hasil uji $\mathrm{t}, \mathrm{H}_{4}$ yang menyatakan bahwa ternyata jika proporsi keberadaan anggota komisaris independen dalam suatu perusahaan akan memberikan dan mempunyai pengaruh signifikan dan berefek secara positif terhadap nilai perusahaan tidak terbuktikan. Dari hasil uji dan analisis yang dilakukan pada penelitian ini, maka menunjukkan dan membuktikan bahwa ternyata proporsi anggota komisaris independen pada perusahaan keluarga tidak berpengaruh secara signifikan namun mempunyai efek positif terhadap nilai perusahaan pada perusahaan keluarga di BEI.

Hasil uji t pada Variabel CEO keluarga menunjukkan dan menyatakan bahwa ternyata ada terdapat pengaruh hubungan yang secara signifikan dan berefek negatif terhadap nilai perusahaan pada perusahaan keluarga. Hal ini membuktikan dari hasil analisis pada penelitian ini dan dapat dinyatakan bahwa dugaan $\mathrm{H}_{1}$ dapat dibuktikan. Perusahaan keluarga yang dijabati oleh CEO non keluarga (profesional) akan lebih baik nilai perusahaannya daripada CEO keluarga. Hal ini dikarenakan bahwa manajer non-keluarga yang professional lebih produktif dibandingkan dari pada manajer keluarga (Hambrick \& Mason, 1984; Kosnik, 1987; Daily \& Dollinger, 1992; Anderson, Dure, \& Reeb, 2009).

Dilihat dari $\mathrm{H}_{2}$ mengenai pengujian pada variabel kualifikasi profesional terhadap nilai perusahaan pada perusahaan keluarga ada pengaruh yang signifikan dan mempunyai efek yang positif, hal tersebut tidak terbuktikan. Hasil pada analisis data pada penelitian ini telah membuktikan dan menunjukkan bahwa adanya kualifikasi profesional yang dimiliki oleh direksi tidak akan memberikan pengaruh yang signifikan terhadap nilai perusahaan pada perusahaan keluarga tetapi adanya kualifikasi professional direksi akan memberikan dan mempunyai hubungan negatif pada nilai perusahaan. Pada umumnya kualifikasi profesional justru akan memberikan profesional judgement yang lebih baik dalam mengambil keputusan, namun perusahaan keluarga cenderung lebih dominan pada keputusan keluarganya dibandingkan pendapat lainnya.

Dilihat dari $\mathrm{H}_{3}$ mengenai penelitian pada hubungan variabel ukuran dewan dan terhadap nilai perusahaan mempunyai pengaruh signifikan yang positif, hal tersebut dapat dibuktikan. Hasil menunjukkan bahwa perusahaan keluarga yang mempunyai banyak anggota dewan direksi yang tercermin dalam ukuran dewan direksi yang besar dapat memberikan pengaruh yang signifikan dan berefek positif terhadap nilai perusahaan pada perusahaan keluarga. Kondisi perusahaan keluarga yang menunjukan bahwa jika semakin besar sebuah ukuran dewan dalam perusahaan keluarga yang artinya semakin banyak anggota dewan direksi di sebuah perusahaan, maka akan mencerminkan semakin efektif mereka dalam memberikan nasihat atau pandangan pada opsi strategi perusahaan karena telah memiliki kemampuan dan sumber daya yang banyak dalam memberikan solusi dalam penyelesaian permasalahan (Pearce \& Zahra, 1991).

\section{KESIMPULAN}

Penelitian yang telah di dilakukan ini adalah bertujuan dan bermaksud untuk menganalisis lebih dalam mengenai apakah ada terdapat pengaruh yang signifikan antara konstruk struktur dewan terhadap nilai perusahaan yang terutama pada perusahaan keluarga. Struktur dewan direksi yang akan digunakan pada penelitian ini adalah CEO Keluarga, kualifikasi profesional, ukuran dewan, dan komisaris independen. Berdasarkan pada hasil analisis data yang telah dilakukan pada sampel 125 perusahan keluarga tahun 2010-2014 maka dapat menyimpulkan dengan ditarik kesimpulan mengenai perusahaan keluarga yang dikelolakan oleh pihak non keluarga (profesional) lebih tinggi nilai perusahaan daripada perusahaan keluarga yang dikelolakan oleh pihak keluarga.

Tata kelola perusahaan merupakan faktor penting yang memungkinkan untuk pengembangan nilai perusahaan milik keluarga. Perusahaan keluarga cenderung kepemilikan keluarganya berpindah dari satu generasi ke generasi berikutnya. Hal ini menjadi kunci pendorong untuk meningkatkan tata kelola perusahaan yang baik untuk mengembangkan dan menyampaikan organisasi yang sehat dan efisien untuk generasi berikutnya.

Kualifikasi profesional pada dewan direksi akan memberikan pengaruh yang signifikan pada nilai perusahaan namun akan berefek hubungan negatif pada perusahaan keluarga. Hal ini diduga bahwa 
jika perusahaan keluarga cenderung lebih dominan pada direksi keluarga dalam pengambilan suatu keputusan yang penting bagi perusahaan keluarga. Ukuran dewan akan mempunyai pengaruh yang signifikan dan berefek secara positif terhadap nilai perusahaan pada perusahaan keluarga. Variabel komisaris indepeden tidak mempunyai hubungan yang signifikan terhadap nilai perusahaan namun ada efek positif terhadap nilai perusahaan pada perusahaan keluarga.

Penelitian ini tak terpungkiri dari keterbatasan. Adapun saran untuk studi lanjut mengenai pembahasan yang serupa dan dapat diberikan untuk digunakan pada penelitian yang akan dilakukan selanjutnya, antara lain yaitu: peneliti selanjutnya diharapkan dapat menambahkan variabel lainnya yang diperkirakan dapat mempengaruhi kinerja yang tercemin bukan hanya pada nilai perusahaan dan membandingkan antar perusahaan keluarga pada berbagai negara.

Budaya dan penerapan strategi masing-masing perusahaan keluarga sangat bervariasi. Maka, kunci strategi perusahaan keluarga untuk mampu bertahan dari satu ke generasi berikutnya merupakan hal yang sangat menarik dan unik untuk diteliti. Perusahaan keluarga mempunyai tantangan terbesar yaitu keberlangsungan hidupnya perusahaan. Keberlangsungan hidup suatu perusahaan dapat dilihat dari kinerja perusahaannya dan apakah perusahaan tersebut sedang mengalami financial distress atau tidak. Dalam rangka menjaga keberlangsungan perusahaaan keluarga perlu dikembangkan dengan penyusunan succession planning mengenai kepemimpinan perusahaan (Wahjono, Wajoedi, \& Idrus, 2014). Hal ini dikarenakan arah yang akan ditujukan oleh perusahaan pada umumnya berada pada tangan pemimpin suatu perusahaan. Pemimpin perusahaan yang akan menentukan nasib hidup matinya keberlangsungan usahanya. Dalam hal mengendalikan suatu perusahaan, pemimpin perusahaan harus bisa membentuk struktur tata kelola perusahaan yang baik.

Hasil penelitian mengenai perusahaan keluarga di Indonesia dengan karakteristik CEO masih sangat sedikit. Oleh karena itu, dengan melakukan penelitian ini diharapkan dapat menghasilkan beberapa temuan yang lebih dan memperkayakan ilmu serta dapat dijadikan sebagai bahan perbandingan hasil antar luar negeri.

Dalam hal kontribusi praktis, hasil penelitian diharapkan dapat memberikan beberapa masukan yang berarti bagi regulator di Indonesia seperti Bappepam (Pasar Modal dan Non-Bank Sektor Keuangan Regulator), akademisi Indonesia, pemilik perusahaan keluarga dan konsultan dalam merancang aturan dan peraturan tata kelola perusahaan bagi perusahaan yang dikendalikan oleh keluarga. Penelitian ini diharapkan dapat mengungkapkan status peringkat nilai perusahaan dikendalikan oleh perusahaan keluarga di Indonesia. Hal ini dapat memberikan informasi yang berharga kepada calon investor pada umumnya mengenai nilai perusahaan potensial pada perusahaan yang akan dilakukan investasi.

\section{UCAPAN TERIMA KASIH}

Penelitian ini dapat dilaksanakan secara lancar karena berkat bantuan dari berbagai pihak. Ucapan terima kasih kami sampaikan kepada Universitas Internasional Batam (UIB) dan RISTEKDIKTI yang telah membantu dalam pelaksanaan dan penulisan serta pembiayaan penelitian ini.

\section{DAFTAR PUSTAKA}

Anderson, R. C., \& Reeb, D. M. (2003). Founding family ownership and business performance: Evidence for the S\&P 500. The Journal of Finance, 58(3), 1301-1328.

Anderson, R. C., Duru, A. \& Reeb, D. M. (2009). Founders heirs and corporate opacity in the United States. Journal of Financial Economics, 92, 205-222.

Belmonte, S. D., Seaman, C., \& Bent, R., (2016). Keeping it in the family: family, priorities and succession in Scottish landed. Journal of Family Business Management, 7(1), 111-121.

Chung, K., Lubatkin, M., Rogers, R., \& Owers, J. (1987). Do insiders make better CEOs than outsiders? Academy of Management Executive, 1, 323-329.

Daily, C. M., \& Dollinger, M J. (1992). An empirical examination of ownership structure in family and professionally manage firms. Family Business Review, 5(2), 11-34.

Darmadi, S. (2013). Board members' education and firm performance: evidence from a developing economy. International Journal of Commerce and Management 23(2), 113-135.

Fairchild, L., \& Li, J. (2005). Director quality and firm performance. The Financial Review, 40(2), 257279. 
Fallatah, Yaser \& Dickins, Denise (2012). Corporate governance and firm performance and value in Saudi arabia. African Journal of Business Management, 6(36), 10025-10034.

Fama, E., F.,\& Jensen, M. C. (1983), "Separation of ownership and control".Journal of Law and Economics, 15(2), 301-325.

Gill, A. \& Obradovich, J. (2012). The impact of corporate governance and financial efek pengungkit on the value of American firms. International Research Journal of Finance and Economics 91.

Hambrick, D.C.,\& Mason, P.A. (1984), "Upper echelons: the organization as a reflection of its top managers", Academy of Management Review, 9, 193-206.

John, K. \& Senbet L. W. (1998). Corporate governance and board effectiveness. Journal of Banking and Finance, 22.

Kosnik, R. (1987). Corporate governance; Directors-of-corporations.Administrative Science Quarterly Journal, 3(1), $163-185$.

Lieyanto, A. \& Indriyani, R. (2014). Penerapan prinsip-prinsip good corporate governance pada perusahaan keluarga pt. prima raya abadi, Surabaya. Agora 2(1).

Limbago, E. \& Juniarti (2014). Pengaruh family control terhadap profitabilitas dan nilai perusahaan pada industri property dan real estate. Business Accounting Review 2(1).

Park, S. Y. \& Shin, H.H (2016). Family control, product market competition and firm performance. Seoul Journal of Economics 29(3).

Pearce II, J. A., \& Zahra, S. A. (1991). The relative power of the CEOs and boards of directors: associations with corporate performance. Strategic Management Journal, 12(2), 135-153.

Rashid, A. (2011). Largest blockholding and firm performance: evidence from an emerging economy. International Research Journal of Finance and Economics, 65, 25-34.

Robin \& Amran, N.A. (2016). Implementation of good corporate governance mechanisms on family firm performance in Indonesia. Advanced Science Letters 22(5/6), 1435-1438.

Villalonga, B., \& Amit, R. (2006). How do family ownership, control and management affect firm value? Journal of Financial Economics, 80(2), 385-417.

Vitor, D. A. (2012). Concentrated share ownership and financial performance. Research Journal of Finance and Accounting, 3(2).

Wahjono, S. I., Wahjoedi, Idrus, S., \& Nirbito, J. G. (2014). Succession planning as an economic education to improve family business performance in east java province of Indonesia. Journal of Asian Scientific Research, 4(11), 649-663.

Yopie, S., \& Itan, I. (2016) CEO-family vs. ceo-nonfamily: Who is a better value creator in family business?, Journal Management Applied Researched, 14(2). 